\title{
INTEGRATED RECYCLING PROCESS OF MATRICES OF ORGANIC MOULDING SANDS
}

\author{
ZINTEGROWANY PROCES RECYKLINGU OSNOWY ORGANICZNYCH MAS FORMIERSKICH
}

The idea and experimental verification of assumptions of the integrated recycling process of matrices of uniform self-hardening moulding sands with synthetic resins, leading to obtaining moulding sands matrix of expected quality - is presented in the hereby paper. The basis of the presented process constitutes a combination of the method of forecasting averaged ignition losses of moulding sands after casting and defining the range of necessary matrix reclamation treatments in order to obtain its full recycling. Simultaneously, the empirically determined dependence of dusts amounts emitted during the reclamation process of the matrix from the given spent sand on the ignition loss values (which is the most proper assessment index of the obtained reclaimed material quality) was taken into account.

The special experimental stand for investigations of the matrix recycling process was one of the elements of the conceptual approach and verification of its assumptions. The stand was equipped with the system of current on-line control of the purification degree of matrix grains from organic binder remains. The results of own investigations, allowing to combine ignition loss values of spent moulding sands after casting knocking out with amounts of dusts generated during the mechanical reclamation treatment of such sands, were utilized in the system.

Keywords: moulding sand, self-setting sand, recycling system, reclamation

W publikacji przedstawiono koncepcję oraz weryfikację doświadczalną założeń zintegrowanego procesu recyklingu osnowy jednolitych samoutwardzalnych mas formierskich z żywicami syntetycznymi, zapewniającego uzyskanie osnowy mas formierskich o oczekiwanej jakości. Podstawę przedstawionego procesu stanowi skojarzenie metody prognozowania autogennych, wywołanych wysoką temperaturą, uśrednionych strat prażenia masy po procesie wykonania odlewu i zdefiniowaniu zakresu dalszej niezbędnej obróbki regeneracyjnej osnowy w celu pełnego jej recyklingu. Równocześnie została uwzględniona empirycznie wyznaczona zależność ilości pyłów emitowanych w czasie procesu odzysku osnowy z danej masy zużytej od wartości strat prażenia, będącego najbardziej właściwym wskaźnikiem oceny jakości uzyskanego regeneratu.

Elementem koncepcji i weryfikacji jej założeń jest realizacja stanowiska doświadczalnego do badań procesu recyklingu osnowy. Stanowisko zostało wyposażonego w system bieżącej kontroli on-line stopnia oczyszczenia ziaren osnowy z pozostałości organicznego spoiwa. W systemie wykorzystano wyniki badań własnych pozwalających na powiązanie wartości strat prażenia w masie zużytej po wybiciu odlewu z ilością generowanych pyłów podczas mechanicznej obróbki regeneracyjnej tej masy.

\section{Introduction}

A matrix recycling is an important problem for the rational management of moulding sands, as a main material of sands with resins being used for making moulds and cores. In case of moulding sands with such binders the notion 'sand circulation' loses its common meaning, used in case of classic moulding sands with bentonite. A moulding sand with resin binder after each cycle of casting production constitutes - in the best case - a by-product, which recycling allows to reclaim up to $95 \%$ of a quartz matrix, being a substitute of a fresh sand.

The idea of an integrated recycling process of matrices from uniform moulding sands with organic binders, which will assure obtaining the matrix of the expected purification degree joins together aspects of preparation of moulding and core sand, basic technological operations: making moulds and cores, pouring, solidification and cooling of castings, castings knocking out, lump crushing and preparation of spent sands for the matrix reclamation process, matrix reclamation process and dedusting and selection of technologically useful grain sizes. This process is based on combining the forecasted averaged ignition losses of the spent moulding sand after casting knocking out with simultaneous correlation of the obtained results with monitoring the amounts of dusts generated during the matrix reclamation in the recycling process. The obtained material, which ignition loss value is known, constitutes then the component of the matrix, and on the basis of its fraction the moulding sand strength value can be forecasted. 


\section{Method of determining ignition losses of spent moulding sand with organic binder after the casting production}

This method was described in details in publications [1]. High temperatures cause self-acting burning of a part of the moulding sand being near the casting, which enables to determine local and averaged ignition losses after the casting production. The effect of 'self-reclamation' in the immediate vicinity of walls, of a part of a moulding sand occurs in the zone in which a moulding sand is heated, by the casting, to a temperature causing a thermal degradation of a binder, which loses its binding and strength properties. The binder being in the sand becomes totally or partially burned out, which improves the matrix knocking out and reclamation (in mechanical systems) ability.

The degradation degree of the whole moulding sand forming the mould, after the casting process performed in this mould, can be determined from the equation [1]:

$D_{m f}=\sum_{T=T_{o t}}^{T_{c d}} \frac{V_{(T)}}{V_{(C)}} \cdot D_{m(T)}=\sum_{T=T_{o t}}^{T_{c d}} \frac{V_{(T)}}{V_{(C)}} \cdot\left(1-\frac{S P_{(T)}}{S P_{(i n i)}}\right) \cdot 100 \%$

$\%$

$\mathrm{D}_{m f}$ - thermal degradation of a moulding sand in a mould,

$\mathrm{T}_{c d}$ - temperature of a total destruction of a binder, ${ }^{\circ} \mathrm{C}$,

$\mathrm{V}_{(T)}$ - volume of a moulding sand heated to a temperature $\mathrm{T}, \mathrm{cm}^{3}, \mathrm{~m}^{3}$,

$\mathrm{V}_{(C)}$ - total volume of a moulding sand, $\mathrm{cm}^{3}, \mathrm{~m}^{3}$,

$\mathrm{D}_{m(T)}$ - relative degree of a moulding sand thermal degradation at a temperature T, \%

$\mathrm{SP}_{(\text {ini })}$ - loss of ignition of the moulding sand, \%,

$\mathrm{SP}_{(T)}-$ loss of ignition of the moulding sand heated to a temperature $\mathrm{T}, \%$.

Knowing the total degree of the moulding sand thermal degradation $\mathrm{D}_{m f}$, it is possible to calculate the spent moulding sand ignition loss, which is determined by the equation:

$$
S P_{(m z)}=S P_{(i n i)}\left(1-0,01 \cdot D_{m f}\right) ; \%
$$

$\mathrm{SP}_{(m z)}$ - spent moulding sand ignition loss, $\%$.

The discussed effect has a different range for different: temperatures, ratio of masses: casting/moulding sand, casting mass and shape, kind of matrix and organic binder as well as for the time during which the casting is in the mould. Knowing the range of this effect for the given binder, at quasi steady-state of other parameters, is very important for the proper realisation of the matrix recycling process, especially when assessments of the forecasted purification degree of grains are performed indirectly on the basis of measured amounts of dusts generated during the process.

Presented equations were experimentally verified [1,2], both during model investigations and at using the results of simulation calculations in the MAGMA program.

Information concerning the ignition loss of spent moulding sands after the casting knocking out is very important for the proper performance of the recycling process. It allows the proper determination of the binder amount left on the spent matrix grains, which should be removed in the mechanical reclamation process as long as the existing technique state allows.

\section{Purification degree of spent moulding sand grains from binder remains}

Purification process of spent moulding sand grains from the binder remains is realised in reclamation processes, mainly mechanical reclamations [3-9]. Reclaimed material is re-used in foundry for production sand moulds and cores as a substitution of fresh sand [10-12].

As the result of performed investigations the influence of the amount of dusts generated in the mechanical reclamation process of spent moulding sands with an organic binder (removed later on in the classification process) on the reclaim ignition loss was calculated. This constituted the grounds of the idea allowing for the indirect assessment of the spent moulding sand ignition loss on the basis of measuring dust amounts generated in the reclamation process. The performed investigations of reclamation, carried out in a rotor tester AT-2 [1,2] concerned three spent moulding sands with synthetic resins (furfuryl resin $\mathrm{F}$, phenolic resin $\mathrm{P}$ and alkyd resin $\mathrm{A}$ ).

The accumulated diagram (Fig. 1) of the results obtained for three kinds of spent moulding sands with organic binders indicates the linear dependence of the reclaimed matrix ignition loss on the amount of after reclamation dusts in the reclaim - for the whole range of the reclamation treatment, regardless of the treatment intensity and its realization time.

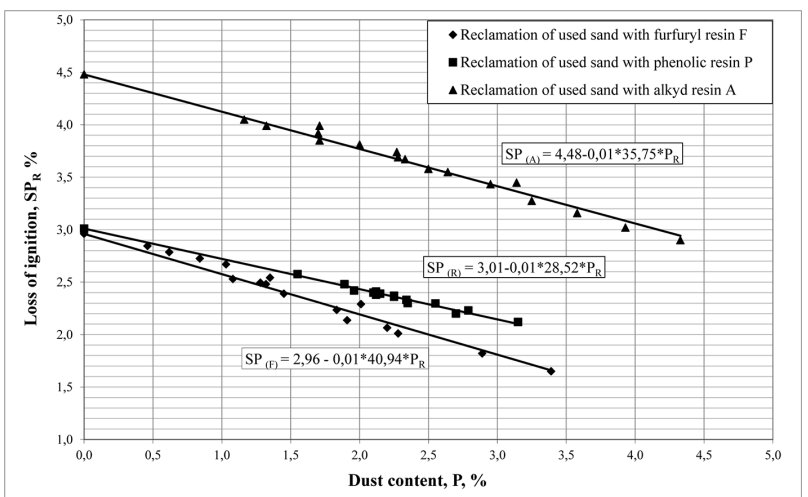

Fig. 1. Accumulated dependence of the reclaimed matrix ignition losses, after the pneumatic classification, on the dusts content generated during the reclaim treatment of three kinds of spent moulding sands in the rotor tester AT-2

The assessment of the degree of reclamation of the spent moulding sand, of known ignition loss before the reclamation, can be indirectly determined on the basis of the forecasted ignition loss of the ready reclaim. Forecasting is done on the basis of measurements of the amount of dusts generated during the process and the knowledge of organic material (resin) content in dusts drawn off from the reclaimer (which - as it was shown in publication [1] - is practically constant during the reclamation process and depends on a binder kind).

Taking into account these data, it can be assumed that the ignition loss of the ready reclaim $\mathrm{SP}_{(R)}$ is expressed by the equation:

$$
S P_{(R)}=S P_{(m z)}-0,01 \cdot S P_{(P)} \cdot P_{R}
$$

$\mathrm{SP}_{(R)}$ - ignition loss of the reclaim, \%

$\mathrm{SP}_{(P)}$ - average ignition loss of dusts, \% 
$\mathrm{P}_{R}$ - amount of dusts drawn off from the reclaimer (\% in relation to the total mass amount in the reclaimer),

$\mathrm{SP}_{(m z)}$ - ignition loss of a spent moulding sand before the reclamation, $\%$,

This - theoretically defined and experimentally verified - regularity can be used as the base of the matrix recycling modern system equipped with automatic measuring and monitoring of dusts. This system is also equipped with the on-line current control of the purification degree of matrix grains from the organic binder remains, which is done by combining ignition losses in the spent sand after casting knocking out with the amount of dusts generated during the matrix mechanical reclamation.

\section{On-line control of the purification degree of the spent moulding sand from binder remains}

The linear dependence, experimentally confirmed, of the amount of dusts generated during the reclamation of spent, uniform moulding sands with organic binders, and ignition loss value of the obtained reclaim, was applied - in the developed system - for the current control of the matrix recycling process. The ignition loss values of the reclaim is - in this system - considered the main index of the degree of liberating polydispersive sand grains from remains of binding materials, while the other, traditionally determined physical and chemical properties of the matrix, play the role of auxiliary factors, suitable at the stage of its integrated assessment.

The experimental stand, designed and built for investigations of the matrix recycling process, was equipped with the current on-line control system of the degree of liberating matrix grains from remains of organic binders with a simultaneous combining ignition loss values in the spent sand after casting knocking out with the amount of dusts generated during the mechanical reclamation treatment of this moulding sand.

The experimental rotor reclaimer, built within the realisation of the own research project [1], marked RD-6, equipped with the system for automatic on-line measurements of amounts of dusts generated in the grinding-crushing treatment is presented in Figure 2.

Reclamation tests of the spent moulding sand with the Kalharz U404 resin hardened by paratoluenesulphonic acid 100T3, were performed in the reclaimer RD-6. The following operation parameters were applied:

METHOD I - rotational speed of the rotor $n=270$ rot./min, time of treatment $\tau_{\text {reg }}=15 \mathrm{~min}$, air rate in the dedusting system $\mathrm{v}_{\text {odp }}=8.5 \mathrm{~m} / \mathrm{s}$. $8.5 \mathrm{~m} / \mathrm{s}$

METHOD II $-\mathrm{n}=540$ rot. $/ \mathrm{min}, \tau_{\text {reg }}=15 \mathrm{~min}, \mathrm{v}_{\text {odp }}=$

METHOD III $-\mathrm{n}=810$ rot. $/ \mathrm{min}, \tau_{\text {reg }}=15 \mathrm{~min}$, air rate in the dedusting system $\mathrm{v}_{\text {odp }}=8.5 \mathrm{~m} / \mathrm{s}$.

METHOD IV - rotor speed $n$ being changed during the reclamation treatment: cycle 1: $\tau_{1 \text { reg }}=0-1 \mathrm{~min}, \mathrm{n}_{1}=270$ rot. $/ \mathrm{min}$, cycle 2: $\tau_{2 \text { reg }}=1-10 \mathrm{~min}, \mathrm{n}_{2}=540$ rot. $/ \mathrm{min}$, cycle 3: $\tau_{3 \text { reg }}=10-15 \mathrm{~min}, \mathrm{n}_{3}=810 \mathrm{rot} . / \mathrm{min}$. Total treatment time $\tau_{\text {reg }}=15 \mathrm{~min}, \mathrm{v}_{\text {odp }}=8.5 \mathrm{~m} / \mathrm{s}$.

METHOD V - rotor speed $\mathrm{n}$ being changed during the reclamation treatment: cycle 1: $\tau_{1 \text { reg }}=0-1 \min , \mathrm{n}_{1}=270$ rot./min, cycle 2: $\tau_{2 \text { reg }}=1-5 \mathrm{~min}, \mathrm{n}_{2}=540$ rot. $/ \mathrm{min}$, cycle 3: $\tau_{3 \text { reg }}=5-15 \mathrm{~min}, \mathrm{n}_{3}=810$ rot. $/ \mathrm{min}$. Total treatment time $\tau_{\text {reg }}=15 \mathrm{~min}, \mathrm{v}_{\text {odp }}=8.5 \mathrm{~m} / \mathrm{s}$.

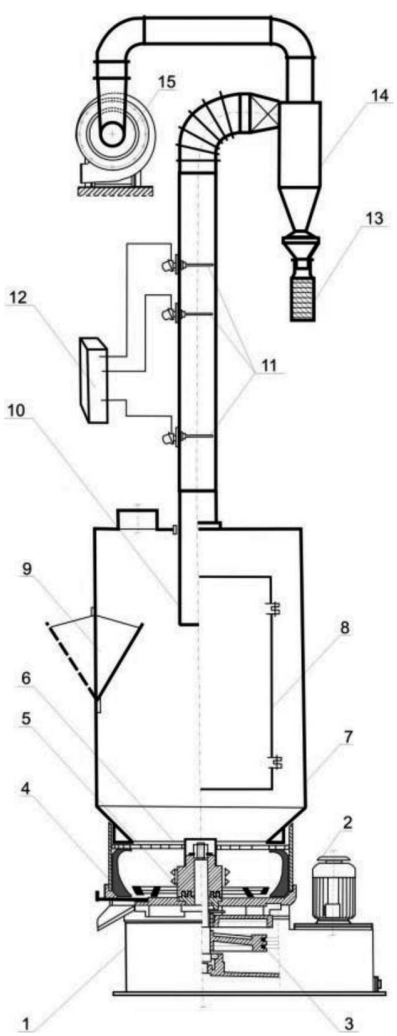

Fig. 2. Scheme of the experimental rotor reclaimer RD-6 equipped with the system of triboelectric dust meter for automatic on-line measurements of amounts of dusts generated in the grinding-crushing treatment of the matrix: 1-base, 2- drive motor, 3-belt transmission, 4-reclaimer ring, 5-rotor with grinding-crushing elements, 6-air guide vanes, 7-casing of the dedusting chamber, 8-inspection door, 9-charge gate, 10-telescopic dedusting conduit, 11-triboelectric dust meter with a system of rate measuring in the dedusting system, 12-converter of signals from triboelectric sensors, 13-dusts reception, 14-cyclone, 15-exhaust fan

Amounts of dusts measured by means of the triboelectric dust meter PM 103D, for the described I-V methods of recycling, are presented as time functions in Figure 3. Ignition loss values $\mathrm{SP}_{(R)}$, are graphically presented in Figure 4.

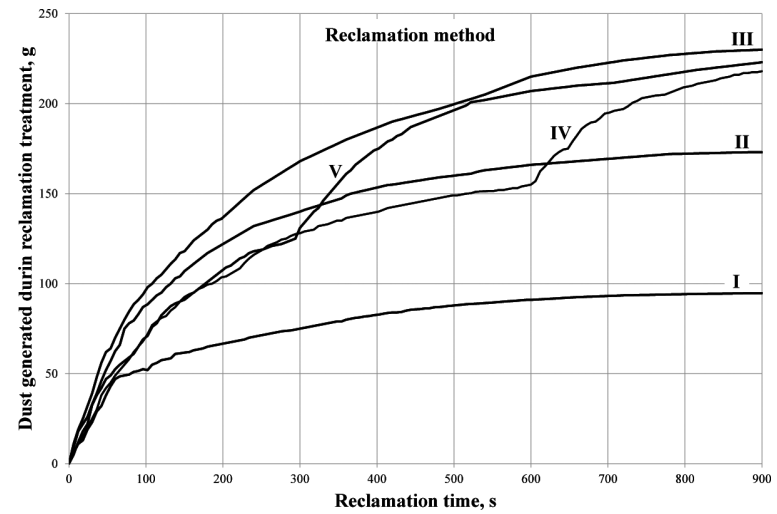

Fig. 3. Accumulated diagram of the dusts content, measured during matrix recycling performed by $\mathrm{I}-\mathrm{V}$ methods 


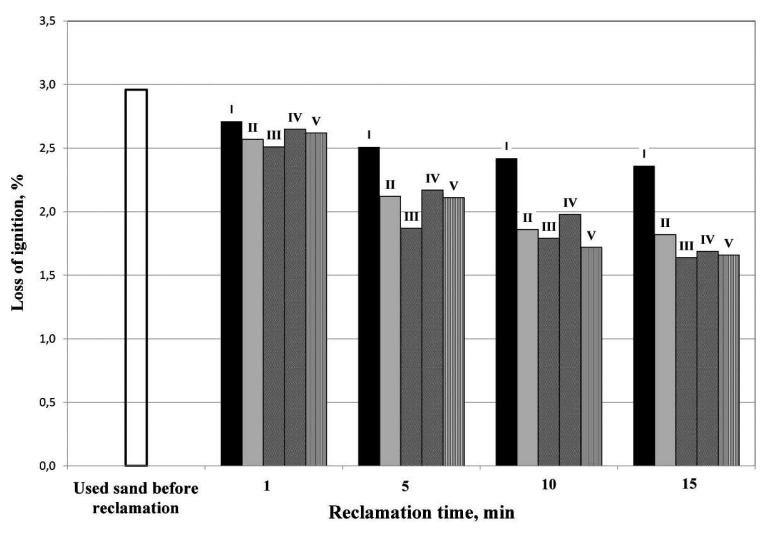

Fig. 4. Ignition loss values of the matrices reclaimed in the recycling process performed according to I-V methods

The detailed investigation results of the effectiveness of the on-line control of the matrix purification from the spent binder remains presented in paper [1] indicates that the developed system is efficient and operates with a high effectiveness.

\section{Conclusions}

The idea and realisation of the integrated recycling process of the matrices from spent uniform moulding sands with organic binders is presented in the paper. The possibility and forecasting method of average ignition loss values of spent moulding sands after the casting knocking out with utilising the simulation calculation of temperature zones (in the MAGMA program) was taken into account in the proposed process. Simultaneously these results were correlated with the monitoring of dusts amounts generated during the matrix reclamation in the recycling process.

In order to verify the developed concept of the integrated process, the experimental reclaimer RD-6 was designed and built. The reclaimer was equipped with the on-line monitoring system of dusts amounts generated in the recycling process, which allowed on-line control of the purification degree of matrix grains from remains of spent organic binders and forecasting ignition losses of the reclaimed material being supplied to the moulding sands preparation plant.

On the grounds of the investigation results presented in the hereby paper and in other works [1,2] it can be stated that, it is possible in the recycling process of matrices of self-hardening moulding sands (organic type) to forecast - by means of the MAGMA program - the average value of the spent sand ignition loss after casting knocking out and then to combine the obtained data with the monitoring of dust amounts generated during the mechanical reclamation treatment of the spent moulding sand.

The integrated recycling process, which is based on a deepened control of the results of matrix ignition losses of moulding sands, prepared with a reclaim, and examinations with regard to their technological properties and environmental impacts provides new possibilities of active influencing its progress in a real time. All this bring nearer to solution, the possibility of obtaining the moulding sand of the expected technological properties in automatic systems of its preparation.

\section{Acknowledgements}

This work was elaborated under research and development study no 11.11.170.318, task 2 .

\section{REFERENCES}

[1] R. D a ń k o, Strength model of self-setting moulding sands with synthetic resins in an aspect oft he integrated matrix recycling process, Archives of Foundry Engineering Publishing House, Gliwice (2012) (in polish).

[2] R. D a ń k o, Archives of Foundry Engineering (2013).

[3] M. Łu c a r z, Metalurgija 47(1), 43 (2008).

[4] R. D a ń k o, Int J Cast Metal Res 23(2), 92-96 (2010).

[5] R. D a ń k o, Metalurgija 50(2), 93-96 (2011).

[6] J.N. W a n g, Z.T. F a n, Int J Cast Metal Res 23(5), 257-263 (2010).

[7] J. J e z i e r s k i, K. J a n e r k a, Metal 2011, 20th Anniversary International Conference on Metallurgy and Materials, 150-155 (2011).

[8] J. D a ń k o, M. H o l t z e r, R. D a ń k o, Metalurgija, 42(3), 173-177 (2003).

[9] I. M a r g i n e a n, C. D u mit r u, A. C r i s a n, Metalurgia International 14, 31-34 (2009).

[10] B. Gr a bow s k a, M. H o $1 \mathrm{tz}$ e r, Arch Metall Mater. 54(2), 427-437 (2009).

[11] J. J a kubski, S. Dobos z, Arch Metall Mater. 52(3), 421-427 (2007).

[12] J. Z y c h, L. J a m r o z ow i c z, Arch Metall Mater. 55(3), 963-968 (2010).

This article was first presented at the VI International Conference "DEVELOPMENT TRENDS IN MECHANIZATION OF FOUNDRY PROCESSES”, Inwałd, 5-7.09.2013 